\title{
Development Game Edutainment Combined with Multimedia Learning to Improve Cognitive and Naturalistic Intelligence At 5-6 Years Old Kindergarten
}

\author{
Evania Yafie \\ Universitas Negeri Malang, Malang, Indonesia \\ e-mail: rosevonia@yahoo.com
}

\begin{abstract}
There is a growing body of evidence supporting the many connections between cognitive competence and game edutainment. This article defines the cluster of concepts related to pretend game and cognition and briefly synthesizes the latest research on the role of such play in children's cognitive and naturalistic intelligence. Edutainment games are a game that includes rules, student guides in practice, awards as a form of appreciation. The combination of interactive multimedia with edutainment games to reduce the weaknesses of each method and media. Multimedia learning can be used to explain games in edutainment games so childreneasy to understanding the command, as well as can be used as media to increase motivation and enthusiasm of children. Game edutainment game utilizes classroom and outdoor especially in the park so it is expected to increase naturalistic intelligence. The purpose of this research is for the development of Edutainment Game Combined with Multimedia Learning which has the level of validity, 2) to overcome the effects of Edutainment Game Combined with Multimedia to Increase Cognitive and Naturalistic Intelligence At 5-6 Year Kindergarten. The research method is research and development (R\&D. The development model adopts the Borg and bile model. This research takes place in TKNBI Tlogowaru Malang. Data analysis used is descriptive model for model validity test and test to analyze model affectivity. The results showed media and method with the level of expert media expertise of $89 \%$, material experts by $91 \%$. The effectiveness test also shows a model of Combined Edutainment With Effective Multimedia Learning In To Improve Cognitive And Naturalistic Intelligence In 5-6 Year TK
\end{abstract}

Keywords: Game Edutainment; Cognitive; Naturalistic Intelligence; Kindergarten; Multimedia Learning

\section{INTRODUCTION}

The play is one approach in the exercise of educational activities for young children. playing in early childhood education (ECD) can use a variety of strategies, methods/materials and media interest, the game can be followed by the child's delight. Through play children are invited to explored (assessment), find and utilize different surrounding. Learning while playing can fun and entertaining for children. Playing for children is a serious but pleasant activity. According to Montessori a true learning emerging from children's freedom to choose their activities and to enhance that require a reformulation of what the meaning of a teacher. In conventional classes have, teachers, usually take a position on the center stage, often strive to encourage and involve a group of children who have high levels of readiness and different ability. Therefore educators when teaching children early age students who still have to be done in a fun way. According play is activity handpicked by children for fun, not for reward or praise. Through play, all aspects of child development can be improved. Play freely with children can explore to reinforce what is already known and discover new things. Through the game, children can also develop all potential optimally, both physical and mental potential intellectual and spiritual. Therefore, play for young children is a bridge to the development of all aspects.

The game is done in the early childhood level requires different types of media and other equipment so that the game becomes more interesting. Gopnik explains that by combining media, learning environment, appropriate methods in the game, then stimulation of the developmental aspects received by the child becomes more leverage. Many types of media can be combined in the game early childhood explains that by leveraging the Games Educational Tool and electronic media such as radio, TV or computer can make a game done by children has become more meaningful so as to improve cognitive memory especially children. 
In this study, researchers developed a game that combined with multimedia media interactive learning games so that the procedures performed by the child becomes more apparent. An interactive multimedia is a form of use of ICT in education. Keep in mind that the practice of early childhood education (ECD) has placed ICT as an essential component both as media and learning materials. Besio (2004) describes some of the role of ICT in early childhood education positions including; 1) ICT as a matter or lesson, 2) ICT as media and learning resources, 3) develop a child's creativity, 4) The role of ICT in enhancing the professionalism of educators, 5) and ICT as a support system administration. Kayode and Olaron ke the integration of ICT in the learning process to improve the effectiveness of early childhood learning in African countries and became one of the keys in order to keep pace with the developing countries as well as developed countries. Bolstad (2004) and Nikolopoulou (2014) explains that the integration of ICT in early childhood learning can not be separated from the three main factors, namely; The first ICT has become part of everyday life of children, in particular, serves as a toy, a means of communication, and entertainment and even social environment of children such as parents and friends. Second, the components contained in the ICT technology offers new opportunities to strengthen various aspects of the practice of early childhood education. Thirdly, there is support for and interest in the education sector as a whole for the development and integration of ICT in education policy and curriculum.

The potential of ICT in enhancing early childhood development has also been confirmed by several previous studies, especially in the United States. The results of the study researchers from the United States (Haugland \& Wright, 1997 ;. Labbo et al, 2003; Clements \& Sarama, 2003; Roskos et al, 2011 ; Parette \& Blum, 2013), Australia (Yelland, 2005; Yelland and Kilderry, 2010; Zevenbergen \& Logan, 2008; Verenikina et al, 2010), British (Stephen and Plowman, 2003; Siraj-Blatchford and Siraj-Blatchford, 2006; Morgan, 2010) and the Netherlands (Segers \& Verhoeven, 2002; McKenney \& Voogt, 2012) suggesting that shows ICT-based learning can be used as a tool to support learning and helps communication, collaboration, creativity, and variety of development in children. Various aspects of development which increased significantly by learning to use a computer, among others language development, particularly cognitive and mathematical cognitive and fine motor development. While aspects of the development of moral values of religious, social, emotional, and gross motor skills require collaboration between ICT with other learning methods to maximize the stimulation of the child's development.

The combination of ICT with the outdoor game is still rarely done by previous researchers. Some researchers who've combines traditional computer game was Siraj-Blatchford and Siraj-Blatchford, which explains that ICT should not be seen as a way to replace or displace other types of traditional games. For example, the use of ICT should not be at the expense of experiences outdoor or indoor that promote the development of gross motor skills through running, climbing, jumping, swinging, and using wheeled toys (Siraj-Blatchford and SirajBlatchford, 2003). Some authors expressed concern that the use of computers is done by a separate motor with physical play activities and creative play open and learning. This most often occurs when "the use of a computer" software visible in drill-andpractice. However, other authors discuss the ways in which ICT can contribute to and support the creative play children through the use of selective and specific supported software applications as well as through the use of many different forms of ICT (for example, a digital camera, programmable toys, or walkie-talkie), both indoors and outdoors, for a variety of learning activities and play different.

Bolgan argues in a more creative and fun to use ICT in kindergarten. ICT is seen by many as opposed to creativity (Bolgan, 2004). However, based on research into the use of digital tools can give kids another opportunity to express themselves in creative ways than traditional tools. Drawing Digital provides opportunities other than traditional images. Such as drawing on the computer is not dependent on the child's motor skills like traditional drawing, offering children the opportunity to design more complex forms and write letters. As demonstrated by Jorgensen, Havn Petersen and Hansen that the computer cannot replace the more traditional art tools and materials, but contribute to new ways to generate an image. Kids get different opportunities to express themselves through color, structure, and form.

The above results indicate that the computer with multimedia components effectively enhance the cognitive development of children. Cognitive development is a very important development towards justice in order to support children to enter elementary school. Children's cognitive abilities required in order to develop his knowledge of what he can see, hear, taste, touch or kiss through the senses. Cognitive behavior involves the ability to think creatively in solving new problems and speed in finding a solution - a new solution in the process of the routine. Thus, education should help children to find hidden treasures in her creativity, and make it really - really able to represent and bring their 
creativity. And for that education needs to understand that indeed children's creativity knows no bounds. Some studies indicate that the computer with multimedia components can improve children's cognitive. Through computer games tutors who do children the ability to know the numbers will increase. As for the way the game's Computer Tutor is a teacher must first turn on the Tutor computer and looking for a game that we will do, teachers take or click on the numbers and will show the number that we want, along with ways of writing and the numerical concept. By utilizing multimedia, children's actively learning to construct knowledge.

In addition to cognitive aspects, this research also wanted to test the effectiveness of a combination of multimedia to improve the game with the naturalistic intelligence. Intelligence naturalistic is the ability of a person who demonstrates proficiency in recognizing and classifying many species (flora and fauna) in the environment, recognize the existence of a species, mapping the relationship between several species, including sensitivity to other natural phenomena (cloud formations, mountains), distinguish inanimate objects and the ability to perceive shapes as well as linking elements that exist in nature.

The naturalist intelligence of children at 4-6 years of age came in the form already begun to have a sense of sensitivity to the surrounding environment, they already have an interest in nature (to observe, engage, look at pictures, collecting elements of plants / animals), caring for and nurturing animals / plants, documented through pictures, and find information through asking, viewing, and reading. The interest in nature shown by the activity observed and investigated the various lives of small creatures such as worms, ants, caterpillars, and so on. Children are also pleased to observe the mound, check out the trail of animals, observing the animals are hiding and arrested. Children who have a naturalistic intelligence tend to like outdoors, familiar with the pets, and often spend time near animals or plants they like. They have a great curiosity about the ins and outs of animals and plants. Children who have a naturalistic intelligence also actively seek information through asking, love to read books and magazines, watch television shows or movies that depict nature.

Based on observations and interviews conducted in the TKN BI Tlogowaru Malang in the class B multiple cognitive aspects in which researchers observe natural center of the field $62.5 \%$ of children, 10 of 16 children in one class have not been able to answer more than three questions every aspect of cognitive learning themes such animals; about a variety of animal sounds, knowing breeding animals, to distinguish animals that live on land, water and air, about the characteristics of the wild animals and livestock, the function of the objects around and get to know plants and animals. Moreover, most of them still show a lack of attention to the surrounding environment. Seen with activity picking crops with caution, littering, and still not be able to participate maintain plants and animals that exist in schools. In addition, they live in rural areas, but less able to enjoy the nature that is around them who actually gives a great potential as a learning tool children, as close to the fields, streams, fish ponds, and so on.

Educational facilities for learning the theme of animals less able to meet the needs of children, especially in the areas of cognition, there are difficulties to be able to learn a wide variety of animals directly. Kids are supposed to get a wide range of knowledge about the animals more. Teachers had tried to complete the learning with visual media, such as miniature or images. However, the media was very limited quantity and variety, shape, and size of the disproportionate, and less attractive to children, the introduction of animals, especially in the field of cognitive any less. Learning computer TKN Tlogowaru BI is already running as local content ranging from class $\mathrm{A}$, so that the children are familiar with and able to control a simple computer. Kids no longer rigid with the computer, like with computers, understand the programs that exist in the computer, familiar symbols in a computer, and is ready for a higher level. However, in the preparation of instructional media used is still limited and less suited to the themes available so that teachers have to sort through more appropriate for the learning process. Based on the above facts then it becomes a problem in the field of machine learning cognitive animal theme for younger children in class B TKN BI Tlogowaru Malang. Writers need to overcome this by developing research.

The purpose of this research is for the development of Edutainment Game Combined with Multimedia Learning the which has the level of validity, 2) to Overcome the effectiveness of Edutainment Game Combined with Multimedia to Increase Cognitive and Naturalistic Intelligence At 5-6 Year Kindergarten.

Multimedia learning developed in TKN BI Tlogowaru Malang, with product specifications, as follows:

Multimedia learning is developed on the theme of animals in class B which contains material about the various animals and their benefits, a variety of wild animals, all kinds of animals by place of his life, animal breeding, animal sounds, animal food, and count the number of animals as well as recognize colors. In addition to the above material learning media is also featuring quizzes, games, 
educational as well as the practice of making animal shapes by folding paper.

This computer-based learning to show concepts based on themes, simple practices and educational games with the discussion in accordance with the indicators of cognitive learning. So that children can have extra knowledge and follow the learning in a fun way.

Computer-based cognitive learning media is produced in the form of a $\mathrm{CD}$ (compact disc)that can be played through a computer. So that the computerbased learning can be used in large classes and individuals.

CD format computer-based cognitive learning media are the * .exe, so it can be opened on any computer without installing a particular program.

Media is interactive learning in which there is button navigation to access many of the desired material while the contents of interactive animations that include video, sound, and pictures of interest.

Multimedia learning can also be used as a tool for teachers in teaching cognitive animal theme because it contains indicators that will be achieved as well as examples of SKH and lesson plans that can be practiced.

Multimedia learning can also be displayed directly to children in cognitive learning animal themes. If there is a trial teacher can practice in class or play a computer-based learning is to children.

In this learning multimedia development researchers also provide product usage guide books and books if the material can be used as a complement.

Edutainment Game is a game that aims to explore the skills of children to identify different species of animals or plants and documentation. The rules in this game are:

Children are given materials about the animals through interactive multimedia from the multimedia children are able to identify the various types of animals live both places classification, benefits, sounds, food, etc.

The teacher collects the child to give an explanation about games Games Edutainment

children were divided into five groups where each group is given a Smartphone to document the animals he encountered.

Give child chance to find different types of animals that exist in school environment than do the documentation.

After documenting the children were collected for counting, mentions, and explain how to protect these animals.

\section{METHODS}

\subsection{Types of Research}

Researchers used a model of development Borg and Gall that there are ten steps of the study. Assessment procedures and the development is not a standard procedure in a study. Research and development are only done in one school that is TKN BI Tlogowaru Malang and subjects used only 40 children, from eight to ten, so that measures research and development is modified, namely: (1) (research and collecting information). Measurement needs, study of literature, research on a small scale, and considerations in terms of value; (2) Planning, Develop a research plan, including the abilities required in the conduct of research, the formulation of the goals to be achieved by the study, design or research steps; (3) Development preliminary form of theproduct. Development of learning materials, learning and evaluation instruments; (4) The initial field trials(preliminary field testing). The test field at 1 to 3 schools with 6 to 12 test subjects (teachers) during the trial was held observation, interviews and questionnaires distribution; (5) revise the results of trials (main product revision). Improve or enhance test results. (6) field trials (main field testing). Test broader at 30 to 100 subjects tested. Quantitative data on teacher performance before and after using the models tested are collected. The results of the data collection are evaluated and, if possible, made the comparison group; (7) the improvement of product field trial results (operational product revision). Enhance product field test results.

\subsection{Trial Product}

In the implementation of the design of product trials, stages proposed design is tested, the test subject, the type of data, data collection instruments and analysis techniques. This is done to determine the feasibility of the product to be developed and manufactured.

\subsection{Design Trial}

Design of the trial was conducted to obtain data that are used to enhance the product to be made, the design of these trials through three stages, namely the evaluation of experts (subject matter experts and learning experts early childhood education), testing (small groups use 6 children as subjects), field trials (large groups using children as subjects 31 ) 


\section{a. Evaluation expert}

Retrieval of data from the experts will be very useful in product enhancements that will be made considering they've experienced in their respective fields. The data collection was done to: (1) two expert learning/game Early Childhood Education; (2) two Cognitive matter experts; (3) two expert instructional media. As the experts in question are as follows:

1) Expert Learning / Early Childhood game, Wuri Astuti, S. Pd. and Aris Sulistyo Wijayadi, S. Pd

2) Material Experts Drs. Ir. Endro Wahyuno, M. Si and Mudrikawati, S. Pd

3) Media expert Henry Praherdiono, S. Si, M. Pd and Yudha Alfian Haqqi, S. Pd

\section{b. Trial Small-group}

The trial conducted on a small group of 6 children in group B TKN BI Tlogowaru Malang is comprised of two children who had less ability, two children who have the ability to moderate, and 2 children that have more capabilities. Small group test is intended to determine the extent to which the products have been produced, and the shortcomings of what should be added that this product can be done in field tests (large group).

\section{c. Trial Large Group and effectivity test}

Large group trials performed in children B1 and B2 groups in TKN BI Tlogowaru Malang with the subject of 31 children.

\subsection{Data Collection Instrument}

Data collection instruments used in the study by using qualitative and quantitative approaches in the form of a questionnaire. This questionnaire was used to collect quantitative data, among others; a. Assessment questionnaires matter experts, instructional specialists and media experts about the validity of the media, c. Assessment of the observer when the small and field research on the cognitive development of the B group and naturalistic intelligence.

\subsection{Data Analysis Techniques}

Data analysis technique used in this research is descriptive analysis techniques through the evaluation of the experts to make use of product test $\mathrm{t}$ test.

Having obtained the results of the data were processed using the above formula, the result is matched with the eligibility criteria as follows:
Table 1 Criteria for eligibility rate (Sudijono 2009)

\begin{tabular}{llll}
\hline Equivalence & Qualification & Percent & Category \\
\hline Decent & Valid & $80 \%-100 \%$ & A (4) \\
\hline Pretty Decent & Enough Valid & $60 \%-79 \%$ & B (3) \\
\hline Less Worthy & Less Valid & $50 \%-59 \%$ & C (2) \\
\hline Improper & Invalid & $0 \%-49 \%$ & D (1) \\
\hline
\end{tabular}

\section{RESULTS}

\subsection{Overview experts about the design of products that will be developed}

The outcome of the review of experts is used as a basis for the revision of the draft learning products developed. A review is undertaken by six experts with two experts qualified Early Childhood Education, two expert material for early childhood cognitive, and two media experts. The purpose of this review was to determine the accuracy and appropriateness of the products are developed with the needs on the ground.

The expert opinion was collected using a questionnaire containing questions. The question in writing.

\section{a. Overview of early childhood learning experts}

In the field of cognitive learning, Multimedia animal theme for the class B that have been made are validated by an expert on early childhood learning. The advice and input from two experts learning early childhood education is; a) selecting an animal that easily found in the environment of children, b) the narrator sounds more hardened than back sound noise and provide additional sound effects every child succeed or not in answer to a quiz, thus adding to the spirit of children and clarify the child's knowledge. From the data assessment learning experts, it can be calculated for the entire items/aspects as follows:

$$
\begin{aligned}
& P=\frac{\sum X}{\sum X_{i}} \times 100 \% \\
& P=\frac{294}{320} \times 100 \%=91.88 \%
\end{aligned}
$$

b. Overview of subject matter experts early childhood cognitive

Once validated by two experts early childhood learning, multimedia cognitive learning in the field of animal theme for the class B and then validated by cognitive matter experts. Based on the evaluation of cognitive matter experts, multimedia learning that has been created by the researchers can be used as early in the development of multimedia products in the field of cognitive learning animal theme for class B. The advice and input from two 
expert cognitive material are; a) should not take a picture with the name of a particular product, $b$ ) the game should be given guidance through the words and the game seemed to child feeding difficulties, c) background on the $\mathrm{CD}$ cover and cover guide less bright. Data assessment experts from such material, it can be calculated for the entire items/aspects as follows:

$$
\begin{aligned}
& \mathrm{P}=\frac{\sum \mathrm{X}}{\sum \mathrm{X}_{\mathrm{i}}} \times 100 \% \\
& \mathrm{P}=\frac{225}{240} \times 100 \%=93.75 \%
\end{aligned}
$$

\section{c. Overview of learning multimedia expert}

Once validated by two experts early childhood cognitive materials, multimedia learning in cognitive field animal theme for the class B and then validated by computer-based media expert. The advice and input from two expert media are; a) The guide book should not be too large to be flexible can be taken anywhere, b) writing the guidebook should be rather large and in print back and forth. From the data assessment of media experts, it can be calculated for the entire items/aspects as follows:

$$
\begin{aligned}
& \mathrm{P}=\frac{\sum \mathrm{X}}{\sum \mathrm{X}_{\mathrm{i}}} \times 100 \% \\
& \mathrm{P}=\frac{304}{320} \times 100 \%=95 \%
\end{aligned}
$$

\subsection{Results from Pilot Small Group}

Test results in small groups to the initial product of multimedia learning in the field of cognitive animal theme for class B derived from observations about the attractiveness, efficiency, and effectiveness in the use of multimedia teaching children in the field of animal cognitive theme carried by one person observer. The respondents' assessment of the data, it can be calculated for the entire items/aspects as follows:

$$
\begin{aligned}
& \mathrm{P}=\frac{\sum \mathrm{X}}{\sum \mathrm{X}_{\mathrm{i}}} \times 100 \% \\
& \mathrm{P}=\frac{45}{48} \times 100 \%=93.75 \%
\end{aligned}
$$

\section{3 of the Group Effectiveness Test Results}

\section{a. Test Results Effectiveness of Cognitive}

Here are the results of data analysis group field trials of the results large group trial by the observers associated with the cognitive aspects of

\begin{tabular}{|c|c|c|c|c|c|}
\hline \multirow[t]{2}{*}{$\begin{array}{l}\text { Perce } \\
\text { ntage } \\
\text { of } \\
\text { "Yes } \\
"\end{array}$} & \multirow{2}{*}{$\begin{array}{c}\text { N ( } \\
\text { Answ } \\
\text { er } \\
\text { ideal) }\end{array}$} & \multicolumn{2}{|c|}{$\begin{array}{c}\text { Data } \\
\text { obtained } \\
\text { by }\end{array}$} & \multirow[t]{2}{*}{ aspects assessed } & \multirow{2}{*}{$\begin{array}{c}\mathbf{N} \\
\mathbf{0}\end{array}$} \\
\hline & & No & $\begin{array}{c}\text { Ye } \\
\text { s }\end{array}$ & & \\
\hline $\begin{array}{c}51.61 \\
\%\end{array}$ & 31 & 15 & 16 & $\begin{array}{l}\text { Understanding to } \\
\text { know and observe } \\
\text { wild animals. }\end{array}$ & 1 \\
\hline $\begin{array}{c}45.16 \\
\%\end{array}$ & 31 & 17 & 14 & $\begin{array}{l}\text { Understanding to } \\
\text { know and } \\
\text { observes the } \\
\text { animals and their } \\
\text { benefits. }\end{array}$ & 2 \\
\hline $\begin{array}{c}38.71 \\
\%\end{array}$ & 31 & 19 & 12 & $\begin{array}{l}\text { Understanding to } \\
\text { know and } \\
\text { observes the } \\
\text { animals that live } \\
\text { on land, in water, } \\
\text { and in the air. }\end{array}$ & 3 \\
\hline $\begin{array}{c}48.39 \\
\%\end{array}$ & 31 & 16 & 15 & $\begin{array}{l}\text { Understanding to } \\
\text { know and } \\
\text { observes various } \\
\text { animal food. }\end{array}$ & 4 \\
\hline $\begin{array}{c}54.84 \\
\%\end{array}$ & 31 & 14 & 17 & $\begin{array}{l}\text { Understanding to } \\
\text { know and observe } \\
\text { the animal } \\
\text { sounds. }\end{array}$ & 5 \\
\hline $\begin{array}{c}38.71 \\
\%\end{array}$ & 31 & 19 & 12 & $\begin{array}{l}\text { Understanding to } \\
\text { know and observe } \\
\text { the breeding } \\
\text { animals. }\end{array}$ & 6 \\
\hline $\begin{array}{c}38.71 \\
\%\end{array}$ & 31 & 19 & 12 & $\begin{array}{l}\text { Understanding } \\
\text { count the animals. }\end{array}$ & 7 \\
\hline $\begin{array}{l}45.16 \\
\%\end{array}$ & 31 & 17 & 14 & $\begin{array}{l}\text { Understanding to } \\
\text { know and observe } \\
\text { the color through } \\
\text { the game. }\end{array}$ & 8 \\
\hline $\begin{array}{l}45.16 \\
\%\end{array}$ & 31 & 17 & 14 & $\begin{array}{l}\text { Understanding to } \\
\text { know and observe } \\
\text { the size of the } \\
\text { long-short, big- } \\
\text { small, low height } \\
\text { with animated } \\
\text { animals. }\end{array}$ & 9 \\
\hline $\begin{array}{l}1238 . \\
71 \%\end{array}$ & 31 & 19 & & $\begin{array}{l}\text { Understanding in } \\
\text { developing } \\
\text { creativity, } \\
\text { memory, and } \\
\text { make } \\
\text { observations with } \\
\text { symbols through } \\
\text { educational } \\
\text { games. }\end{array}$ & 10 \\
\hline 44.52 & & & 13 & & \\
\hline$\%$ & 310 & 172 & 8 & TOTAL & \\
\hline
\end{tabular}
using Edutainment Game Combined with
Multimedia Learning:

Table 2. Data from a large group trial by the observers associated with the cognitive aspect before using

Edutainment Game Combined with Multimedia Learning 
Table 3. Data from a large group trial by the observers associated with the cognitive aspect of using Edutainment

Game Combined with Multimedia Learning

\begin{tabular}{|c|c|c|c|c|c|}
\hline \multirow[t]{2}{*}{$\begin{array}{l}\text { Percentage } \\
\text { of "Yes" }\end{array}$} & \multirow{2}{*}{$\begin{array}{c}\text { N } \\
\text { (Ans } \\
\text { wer } \\
\text { ideal } \\
\quad \text { ) }\end{array}$} & \multicolumn{2}{|c|}{$\begin{array}{c}\text { Data } \\
\text { obtained } \\
\text { by } \\
\end{array}$} & \multirow[t]{2}{*}{ Aspects assessed } & \multirow[t]{2}{*}{ No } \\
\hline & & $\begin{array}{l}\mathbf{N} \\
\mathbf{0}\end{array}$ & $\begin{array}{c}\mathrm{Ye} \\
\mathbf{s}\end{array}$ & & \\
\hline $90.32 \%$ & 31 & 3 & 28 & $\begin{array}{l}\text { Understanding to know } \\
\text { and observe wild } \\
\text { animals. }\end{array}$ & 1 \\
\hline $77.42 \%$ & 31 & 7 & 24 & $\begin{array}{l}\text { Understanding to know } \\
\text { and observe the animals } \\
\text { and their benefits. }\end{array}$ & 2 \\
\hline $83.87 \%$ & 31 & 5 & 26 & $\begin{array}{l}\text { Understanding to know } \\
\text { and observe the animals } \\
\text { that live on land, in } \\
\text { water, and in the air. }\end{array}$ & 3 \\
\hline $90.32 \%$ & 31 & 3 & 28 & $\begin{array}{l}\text { Understanding to know } \\
\text { and observe various } \\
\text { animal food. }\end{array}$ & 4 \\
\hline $90.32 \%$ & 31 & 3 & 28 & $\begin{array}{l}\text { Understanding to know } \\
\text { and observe the animal } \\
\text { sounds. }\end{array}$ & 5 \\
\hline $90.32 \%$ & 31 & 3 & 28 & $\begin{array}{l}\text { Understanding to know } \\
\text { and observe the } \\
\text { breeding animals. }\end{array}$ & 6 \\
\hline $90.32 \%$ & 31 & 3 & 28 & $\begin{array}{l}\text { Understanding count } \\
\text { the animals. }\end{array}$ & 7 \\
\hline $93.55 \%$ & 31 & 2 & 29 & $\begin{array}{l}\text { Understanding to know } \\
\text { and observe the color } \\
\text { through the game. }\end{array}$ & 8 \\
\hline $83.87 \%$ & 31 & 5 & 26 & $\begin{array}{l}\text { Understanding to know } \\
\text { and observe the size of } \\
\text { the long-short, big- } \\
\text { small, low height with } \\
\text { animated animals. }\end{array}$ & 9 \\
\hline $87.10 \%$ & 31 & 4 & 27 & $\begin{array}{l}\text { Understanding to } \\
\text { develop creativity, } \\
\text { memory, and make } \\
\text { observations with } \\
\text { symbols through } \\
\text { educational games. }\end{array}$ & 11 \\
\hline $88.56 \%$ & 341 & 39 & $\begin{array}{c}30 \\
2\end{array}$ & TOTAL & \\
\hline
\end{tabular}

Based on the analysis of field trials of the 31 children in group B in TKN BI Tlogowaru known that before using Edutainment Game Combined with Multimedia Learning cognitive mastery that whereas $44.52 \%$ after using Edutainment Game Combined with Multimedia Learning increased become 88.56 $\%$. Thus the results of the classification percentage are between $80 \%-100 \%$ belong to the good classification (used). further based on the results of t-test is known that the significant value of 0000 or the $p$ value of $<0.05$ so that it can be concluded that the Edutainment Game Combined with Multimedia
Learning effectively improve the cognitive abilities of children.

\section{b. Naturalistic Intelligence Effectiveness Test Results}

Here are the results of data analysis field trial large group large groups of test results by the observers related to aspects of naturalistic intelligence using Edutainment Game Combined with Multimedia Learning:

Table 4. Data from a large group of trial by the observers related to aspects of intelligence naturalistic before using Edutainment Game Combined with Multimedia Learning

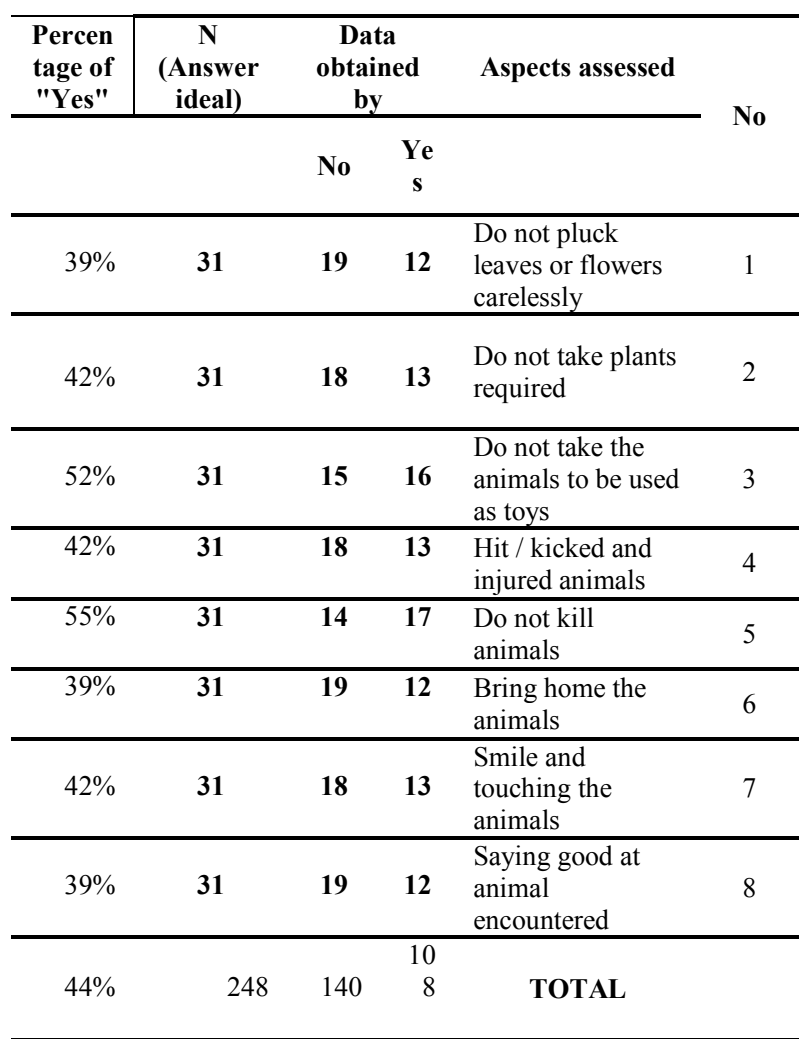


Table 5. Data from a large group trial by the observers related to aspects of naturalistic intelligence before using Edutainment Game Combined with Multimedia Learning

\begin{tabular}{|c|c|c|c|c|c|}
\hline \multirow[t]{2}{*}{$\begin{array}{l}\text { Percen } \\
\text { tage of } \\
\text { "Yes" }\end{array}$} & \multirow[t]{2}{*}{$\begin{array}{c}\mathbf{N} \\
\text { (Answ } \\
\text { er } \\
\text { ideal) } \\
\end{array}$} & \multicolumn{2}{|c|}{$\begin{array}{l}\text { Data obtained } \\
\text { by }\end{array}$} & \multirow[t]{2}{*}{ Aspects assessed } & \multirow[t]{2}{*}{$\mathbf{N}$} \\
\hline & & No & Yes & & \\
\hline $81 \%$ & 31 & 6 & 25 & $\begin{array}{l}\text { Do not pluck } \\
\text { leaves or flowers } \\
\text { carelessly }\end{array}$ & 1 \\
\hline $74 \%$ & 31 & 8 & 23 & $\begin{array}{l}\text { does not take } \\
\text { plants required }\end{array}$ & 2 \\
\hline $87 \%$ & 31 & 4 & 27 & $\begin{array}{l}\text { did not take the } \\
\text { animals to be used } \\
\text { as a toy }\end{array}$ & 3 \\
\hline $77 \%$ & 31 & 7 & 24 & $\begin{array}{l}\text { not hit/kicked and } \\
\text { injured animals }\end{array}$ & 4 \\
\hline $74 \%$ & 31 & 8 & 23 & Not kill animals & 5 \\
\hline $90 \%$ & 31 & 3 & 28 & $\begin{array}{l}\text { Bring home the } \\
\text { animals }\end{array}$ & 6 \\
\hline $77 \%$ & 31 & 7 & 24 & $\begin{array}{l}\text { Smile and } \\
\text { touching the } \\
\text { animals }\end{array}$ & 7 \\
\hline $87 \%$ & 31 & 4 & 27 & $\begin{array}{l}\text { Saying good at } \\
\text { animal } \\
\text { encountered }\end{array}$ & 8 \\
\hline $81 \%$ & 248 & 47 & 201 & TOTAL & \\
\hline
\end{tabular}

Based on the analysis of field trials of the 31 children in group B in TKN BI Tlogowaru known that before using Edutainment Game Combined with Multimedia Learning intelligence naturalistic further $44 \%$, while after using Edutainment Game Combined with Multimedia Learning increased to $81 \%$. Thus the results of the classification percentage are between $80 \%-100 \%$ belong to the good classification (used). Further based on the results of t-test is known that the significant value of 0000 or the $p$ value of $<0.05$ so that it can be concluded that the Edutainment Game Combined with Multimedia Learning effectively improve child naturalistic intelligence.

\section{Product Revision}

Revision of multimedia products in the field of cognitive learning in terms of the animal theme, namely learning experts; a) selecting an animal that easily found in the environment of children, b) the narrator sounds more hardened than backsound noise and provide additional sound effects every child succeed or not in answer to a quiz, thus adding to the spirit of children and clarify the child's knowledge. While the revision of subject matter experts, namely; a) should not take a picture with the name of a particular product, b) the game should be given guidance through the words and the game seemed to child feeding difficulties, c) background on the $\mathrm{CD}$ cover and cover guide less bright. Overview of media experts, namely; a) The guide book should not be too large to be flexible can be taken anywhere, $b$ ) writing the guidebook should be rather large and in print back and forth. Before conducting small group test, researchers have revised the media.

Revised test observations of small groups, namely; a) the use of the media for a scene specificmust be guided by the teacher, should study conducted jointly open the same material and there is a child play games for free so that when the children trouble the teacher can immediately help, b) game feeding the animals is too difficult for a child, so it should be replaced with animal education another game. Before field test study a large group of researchers has been revised. Based on the results of the field test data analysis of a large group, it can be concluded that learning multimedia products in the field of cognitive animal theme for the class B does not need to be revised. These products can already be used as an alternative medium of learning interesting, efficient, and effective for children.

\section{CONCLUSIONS}

1. OverallBased on the data obtained from learning experts, Edutainment Game Combined with Multimedia Learning has a validity value of $91.88 \%$ with a valid category.

2. Based on the overall data obtained from early childhood materials experts, Edutainment Game Combined with Multimedia Learning has a validity value of $93.75 \%$ with a valid category.

3. Based on the overall data obtained from media experts, Edutainment Game Combined with Multimedia Learning has a validity value of $95.00 \%$ with a valid category.

4. Game Edutainment product Combined with Multimedia Learning effectively improve children's cognitive.

5. Game Edutainment product Combined with Multimedia Learning effectively improve child naturalistic intelligence. 


\section{REFERENCES}

[1] Suyadi \& Ulfah, Maulidya . 2013. Konsep Dasar Paud. Bandung: Remaja Rosdakarya

[2] Muharnis. 2007. Perkembangan Kemampuan Berbahasa Anak. Dinas Pendidikan

[3] Risaldy, Sabil. 2014. Bermain, Berceritadan Menyanyi. Jakarta : Luxima.

[4] Gopnik, A. 2012. Scientific thinking in young children: Theoretical advances, empirical research, and policy implications. Journal Science, 337, 1623-1627

[5] Hirsh-Pasek, K., \& Golinkoff, R. 2003. Einstein Never Used Flashcards: How Our Children Really Learn And Whythey Needto Playmore Andmemorize Less. Emmaus, PA: Rodale Press.

[6] [6]Besio, S. 2004. Using Assis_ve Technologies to Facilitate Play by Children with Motor Impairment: A Methodological Proposal. Technology \& Disability, 16 (3): 119-131

[7] Kayode, Olowe Peter dan Olaronke. Kutelu Bukola . 2014. Perceived Importance of ICT in Preparing Early Childhood Education Teachers for The New Generation Children. International Journal of Evaluation and Research in Education (IJERE) Vol.3, No.2, June 2014, pp. 119 124

[8] Nikolopoulou, Kleopatra. 2014. ICT Integration in Preschool Classes: Examples of Practices in Greece. Journal Faculty of Early Childhood Education, School of Education, University of Athens, Athens, Greece

[9] Bostald, 2004. The role and potential of ICT in early childhood education A review of New Zealand andinternational literature. Wellington : Council For Educational Research Te Rūnanga $\mathrm{O}$ Aotearoa Mō Te Rangahau I Te Mātauranga

[10] Haugland, Susan W. 2000. Computers and Young Children. Eric Digest

[11] Labbo, L., Leu, D., Kinzer, C., Teale, W., Cammack, D., Kara-Soteriou, J., \& Sanny, R. (2003). Teacher Wisdom Stories: Cautions and Recommendations for Using ComputerRelated Technologies for Literacy Instruction. Journal The Reading Teacher, 57, 300-304

[12] Clements, D., \& Sarama, J. 2003. Strip Mining for Gold: Research and Policy in Educational Technology-A Response to "Fool's Gold". Educational Technology Review, 11, 7-69.

[13] Roskos, K., Burstein, K., You, B. K., Brueck, J., \& O'Brien, C. (2011). A Formative Study of an E-Book Instructional Model in Early Literacy. Creative Education, 2, 10-17.

[14] Parette, H., Quesenberry, A., \& Blum, C. 2010. Missing the Boat with Technology Usage in Early Childhood Settings: A 21st Century View of Developmentally Appropriate Practice. Early Childhood Education Journal, 37, 335-343.

[15] Yelland, N. 2005. Curriculum, Pedagogies and Practice with ICT in the Information Age. In N. Yelland (Ed.), Critical Issues in Early Childhood Education (pp. 224-242). Milton Keynes: Open University Press.

[16] Yelland, N., \& Kilderry, A. (2010). Becoming Numerate with Information and Communications Technologies in the TwentyFirst Century. International Journal of Early Years Education, 18, 91-106

[17] Zevenbergen, R., \& Logan, H. 2008. Computer Use by Preschool Children: Rethinking Practice as Digital Natives Come to Preschool. Australian Journal of Early Childhood, 33, 37 44.

[18] Verenikina, I., Herrington, J., Peterson, R., \& Mantei, J. 2010. Computers and Play in Early Childhood: Affordances and Limitations. Journal of Interactive Learning Research, 21, 139-159.

[19] Siraj-Blatchford, I., Siraj-Blatchford, J. 2006. A Guide to Developing the ICT Curriculum for Early Childhood Educa_on. Trebtham Books, UK.

[20] Morgan, A. 2010. Interactive Whiteboards, Interactivity and Play in the Classroom with Children Aged Three to Seven Years. European Early Childhood Education Research Journal, 18, 93-104.

[21] McKenney, S., \& Voogt, J. 2010. Technology and Young Children: How 4-7 Year Olds Perceive Their Own Use of Computers. Computers in Human Behavior, 26, 656-664.

[22] McCarrick, K., \& Li, X. 2007. Buried Treasure: The Impact of Computer Use on Young Children's Social, Cognitive, Language Development and Motivation. AACE Journal, 15, 73-95.

[23] Siraj-Blatchford, J., Whitebread, D. 2003. Suppor_ng Informa_on and Communica_on Technology in the Early Years. Suppor_ng Early Learning. Open University Press, UK.

[24] Bolgan, N. 2004. Early Learners and the Use of Information and Communication Technology (ICT) in Kindergarten/Pre-school. Paper presented at the 2nd NEOTHEMI Conference 
on Cultural Heritage and ICT. Theory and Practice, University of Helsinki, Finland, September 2003. Retrieved Juni 20, 2017, from http://www.edu.helsinki.fi/tt/neothemi/Neothe mi2.pdf

[25] Moberg, L. M. \& Lindén, N. 2008. Barn og kommunikasjon. Om små barns bruk og utforsking av digitale verktøy. Oslo: Gyldendal

[26] Jørgensen, L., Havn Pettersen, L. \& Hansen, S. E. 2005. Computerskaberi. Esbjerg: CVU Vest Press

[27] Cohen, R. 1994. How New Technologies Ques_on Educa_onal Prac_ces and Learning Theories. In: Wright, J. and Benzie, D. (eds.). Exploring a New Partnership: Children, Teachers and Technology. IFIP and NorthHolland, Amsterdam: 89-95.

[28] Byron, T. 2008. Safer Children in a Digital World. The Report of the Byron Review. Department for Children, Schools and Families Publica_ons, Sherwood Park, UK.

[29] Amstrong, T. 2002 Penjajakan Pemahaman Dan Pelaksanaan Pendidikan Yang Berorientasi Pada Multiple intellegenciesdi Lembaga-Lembaga Pendidikan Anak Usia Dini. laporan penelitian Yogjakarta : Lemlit UNY

[30] Sujiono, Yuliani Nurani. 2009. Konsep Dasar Pendidikan Anak Usia Dini. Jakarta: indeks

[31] Musfiroh, Tadkiroatun. 2008. Cerdas Melalui Bermain. Jakarta: Grasindo.

[32] Amstrong, T. 2005. Sekolah Para Juara Multiple intellegencies Di Dunia Pendidikan (Alih Bahasa : Muntaro, Yudi Bandung : Kaifa.

[33] Borg, W. R. dan Gall, M. D. 1983. Educational Research An introduction. New York: Longman 